\title{
Strategic fit between business strategies in the post- acquisition period and acquisition performance*
}

\author{
Matej Lahovnik**
}

The overwhelming empirical evidence suggests that, from the acquirer's perspective, acquisitions are mostly at best "break-even" situations and at worst failures. Our study seeks to contribute to this pool of knowledge by analysing the performance of horizontal acquisitions. We examined the performance of horizontal acquisitions regarding the strategic fit between the business strategies of acquiring and acquired companies in the post-acquisition period. Horizontal acquisitions in which the acquiring and acquired companies developed an identical type of business strategy in the post-acquisition period outperformed acquisitions where the acquiring and acquired companies developed different types of a generic business strategy. The results suggest that the sharing of activities and transfer of skills are important in cases of a fit between business strategies in the post-acquisition period.

Eine überwältigende Anzahl empirischer Hinweise lässt darauf schließen, dass aus der Übernehmersicht betrachtet - die meisten Akquisitionen bestenfalls Break-even Situationen darstellen oder schlimmstenfalls zu Ausfällen führen. Unsere Studie versucht, mit der Analyse von horizontalen Akquisitionen, einen Beitrag zum gegenständlichen Wissenspool zu leisten. Somit wurde die Leistung horizontaler Akquisitionen im Hinblick auf ihre strategische Eignung, d.h. auf den Anpassungs- bzw. Übereinstimmungsgrad der Geschäftsstrategien beider Unternehmen in dem Zeitabschnitt nach der Übernahme untersucht. Es hat sich gezeigt, dass horizontale Akquisitionen, bei denen das übernehmende und das übernommene Unternehmen in dem erfassten Zeitabschnitt den selben Typ von Geschäftsstrategie anwendeten, bessere Resultaten aufwiesen als solche, bei denen beide Partner sich nach wie vor unterschiedlicher Business-Strategien bedienten. Das legt den Schluss nahe, dass eine gemeinsame Nutzung von Aktivitäten sowie des Wissenstransfers nur dann von grundlegender Bedeutung sind, wenn die Geschäftsstrategien der Partner aufeinander abgestimmt werden.

Key words: strategy, acquisition, performance, strategic fit

* Manuscript received: 22.07.2011, accepted 07.09.2011 (1 revision)

** Matej Lahovnik, PhD, Associate professor, Faculty of Economics, Ljubljana. Main research areas: Strategic management, corporate governance, mergers and acquisitions. Corresponding address: matej.lahovnik@uni-lj.si 


\section{Introduction}

Mergers and acquisitions have been the most popular growth strategy for decades in the US economy. The 1990s and 2000s also featured a markedly increased volume of European mergers and acquisitions. Economic growth, deregulation and the development of the common European economy accelerated the acquisition process in EU countries. The number of acquisitions has also risen in economies in transition. Horizontal acquisitions are the most popular and most frequently pursued acquisition type. From the strategic perspective, the key questions are whether and how an acquirer will restructure the company, and how this will contribute to the acquired company's competitive advantage. However, the overwhelming empirical evidence suggests that, from the acquirer's perspective, acquisitions are mostly at best "break-even" situations and at worst failures. We seek to contribute to this pool of knowledge by analysing the performance of horizontal acquisitions in a small open economy. Three classic generic strategies seemed to yield a special competitive advantage: low-cost leadership, differentiation, and focus. The purpose of this paper is to reveal the main factors that have pushed companies to develop a strategy of horizontal acquisition and to explore what kind of role is played by the strategic fit between companies engaged in the same type of business. We therefore examined the performance of horizontal acquisitions regarding the strategic fit between the business strategies of acquiring and acquired companies in the post-acquisition period. Our research in based on an analysis of 43 cases of acquisitions in Slovenia. We focused our research on the relationship between the business strategies of companies involved in an acquisition. Our basic research hypothesis is that companies should pursue an identical type of generic business strategy within the same industry in the postacquisition period in order to realise the most important synergies. We formulated three subsidiary hypotheses:

$H_{1}$ : There are statistically significant differences among motives for horizontal acquisitions regarding the type of generic business strategy that it is pursued in the post-acquisition period.

$\mathrm{H}_{2}$ : There are perceived performance differences between acquisitions where companies develop an identical type of business strategy and acquisitions where companies develop different types of business strategies in the post-acquisition period.

$H_{3}$ : Realisation of the motives for the acquisition leads to increasing value added per employee in the acquired company.

We argue that the management of companies involved in a horizontal acquisition should pay more attention to the strategic fit between generic business strategies. The co-ordination of various activities between the merged companies is very difficult or even impossible if they try to compete by pursuing 
different generic business strategies within the same industry. The paper proceeds as follows. The next section briefly deals with some important theoretical issues. The third section explains the characteristics of the business environment in Slovenia. In the fourth section we explain how we conducted the research. The empirical results are presented in the fifth section. In the last section, we offer some conclusions.

\section{Theoretical background}

Different management tools like total quality management, benchmarking, timebased competition, outsourcing, partnering and reengineering that are used today do enhance and dramatically improve the operational effectiveness of a company, but fail to provide the company with sustainable profitability. Porter (1996) states that a company can outperform its rivals only if it can establish a difference it can preserve. It must deliver greater value to customers or create a comparable value at a lower cost, or do both. Competitive strategy is about being different. It means deliberately choosing a different set of activities to deliver a unique mix of value. Moreover, the essence of strategy, according to Porter, is choosing to perform activities differently than rivals do. Strategy is the creation of a unique and valuable position, involving a different set of activities. Strategic fit is fundamental not only to competitive advantage but also to the sustainability of that advantage because it is harder for a competitor to match an array of interlocked activities than it is merely to replicate an individual activity. Companies often grow by extending their product lines, adding new features, imitating competitors' popular services, matching processes, and making acquisitions. Most companies start with a unique strategic position involving clear trade-offs. However, they often fall into a "growth trap". With the pressures of growth, acquirers are led to make compromises which are, at first, almost imperceptible. Thus, through a succession of incremental changes which seemed sensible at the time, companies have compromised their way to homogeneity with their rivals. Compromises and inconsistencies in the pursuit of growth eventually erode the competitive advantages of a company and their uniqueness. It could be argued that, to be successful, a business unit must achieve one specific generic business strategy (Porter 1996): cost leadership, differentiation or focus. Otherwise, the business unit will become stuck in the middle of the competitive marketplace with no competitive advantage and be doomed to a below-average performance.

Strategic relatedness between the acquiring and target companies is therefore one of the key issues influencing the performance of an acquisition. Acquirers find it less difficult to determine which acquisition strategies to pursue rather than how to actually implement them. A survey of over 200 top European executives concluded that the challenge of integrating the newly acquired companies was the most important one (Cartwright/Cooper 1993). Choosing the right partner is critical. However, even if an acquirer chooses wisely it may still 
reduce the performance by integrating the two companies together too roughly. Industry observers have therefore identified post-acquisition integration as being critical to long-term acquisition success (Gruca et al. 1997; Very et al. 1997; Norburn/Schoenberg 1994; De Noble et al. 1988).

Empirical evidence suggests that, from the acquirer's perspective, acquisitions are mostly at best "break-even" situations and all-too-often failures (Gates/Very 2003; Norburn/Schoenberg 1994; Berkovitch/Narayanan 1993; Morck et al. 1990; Lubatkin 1983). Some studies have found that 33\% to 50\% of acquisitions were later divested, giving corporate marriages a divorce rate roughly comparable to that of men and women (Porter 1987; Bradley et al. 1988; Jarrell et al. 1988). The results from the three different measures in the recent study indicated failure rates from 50\% to 60\% (Papadakis/Thanos 2010). Forming a larger firm may have the benefit of economies of scale. However, the argument that horizontal acquisitions occur to realise economies of scale is not sufficient to explain why this type of acquisition prevails. The issue of capability transference is also fundamental to explaining horizontal acquisitions. Strategic positions should have a long-term horizon as continuity promotes improvements in individual activities and the fit across activities, allowing an organisation to build unique capabilities and skills custom-fitted to its strategy.

\section{The business environment in Slovenia}

Slovenia is an open, export-oriented economy and is committed to open markets. It is an integral part of the common internal EU market. The number of acquisitions in economies such as Spain or Greece increased radically after they had entered the European Union, and this has happened also in the Eastern European Economies post 2004. Among those transition economies that entered the new larger Europe, the Slovenian economy is perhaps the most developed, with a GDP of approx. 88\% of average GDP in the European Union. Scholars argue that the Slovenian economy has faced an intensive restructuring process in the last decade on the corporate level (Penger/Tekavčič 2008; Dervarič et al. 2008; Lahovnik 2010; Žnidaršič 2010). Mergers and acquisitions of firms are one of the most important forms of the restructuring process. However, companies still measure their performance unsystematically since only 38 percent of companies use some form of integrated performance measurement system (Peljhan et al. 2010). In a study on a sample of 172 Slovenian companies, some other scholars (Čater/Pučko 2010) reveal that managers in Slovenia mostly rely on planning and organising activities when implementing strategies, while the biggest obstacle to strategy execution is poor leadership. Potential foreign investors outside the EU have been used the Slovenian economy as a springboard for penetrating the internal EU market.

The ownership structures that have emerged from the variety of privatisation programmes in the post-communist economies have not produced concentrated 
ownership in the hands of outsiders who are able provide the required resources to finance growth, modernise technology, deliver marketing skills, etc.. Slovenia is not an exception. Some companies are still controlled by governmental agencies. The privatisation process is incomplete, financial and labour markets are underdeveloped and certain structural changes are still to be accomplished. The acquirers in the Post-Communist economies are still often faced with the challenge of how to completely restructure acquired companies. Motives such as transferring skills and sharing activities prevail. Business practices have been for many years completely different to Western European norms. Slovenia is committed to continuing with programmes for the privatisation of companies in direct or indirect state ownership, although now is not the best time for these activities. There is still a process of the state's accelerated exit from company ownership in the portfolios of state funds, i.e. the capital fund (KAD) and the restitution fund (SOD). In those companies that will retain an important share of state ownership, considerable improvements are taking place in corporate governance in accordance with the OECD's Principles and Guidelines on corporate governance, especially of state-owned enterprises. An open dialogue on the standards of business conduct, also fuelled by the circumstances of the current crisis, has been ongoing for some time. Steps are being taken to better define the role of the state in the economy and that of private business initiative as well as respective responsibilities. Foreign acquisitions into Slovenia that are included in our research have been following a well-established pattern. Having in mind the size of the economy, foreign investors have achieved good results. They are as a rule long-term oriented, rather than being oriented to short-term profit. Investments are not based on low-labour costs but on technical skills and Slovenia's relative geographical position. Most existing foreign investments have expanded in the course of years. A survey was recently conducted to gauge the degree of foreign investors' satisfaction in Slovenia in which the question of their motives for investing in Slovenia as a small economy is very revealing. By structure, manufacturing foreign subsidiaries are distinctly export-oriented.

\section{Methodology}

A person or company which acquires a share in a joint-stock company's voting stock in Slovenia such that this stock, together with other existing securities in its portfolio, provides it with no less than $25 \%$ of the voting rights, must submit a public takeover bid to acquire these securities. Prior to submitting the takeover bid, the bidder must announce its intention of submitting the takeover bid to the Securities and Exchange Agency, which plays a crucial regulatory role in the acquisition process in Slovenia. In the 1998-2008 period, 195 takeover bids were announced in Slovenia, 177 of which were successfully implemented. In seven cases the target was a bank whereas in 38 cases the target was another financial institution. We focused our research on successfully implemented 
takeover bids that met certain criteria. The acquired firm had to have specific characteristics to fall within the research sample:

- at least 250 employees;

- at least USD 5 million in annual income;

- not a bank or other financial institution;

- a joint-stock company; and

- to be engaged in the same type of business activity as the acquirer.

Our empirical research was based on a fully-structured interview prepared with pre-coded responses. The research sample included 43 horizontal acquisitions from electrical industry, metal industry, chemical industry and food processing industry as well as from service sector (retailing). In 17 cases the acquirers were the foreign companies. The companies had been acquired in the 1998-2008 period. We defined horizontal acquisition as the case where firms are operating and competing in the same kind of business activity. The managers who answered the questionnaires had been included from the start of the acquisition process and were well aware of all strategic factors that determined the acquisition. Managers were asked to name the generic business strategies of the acquirers and those of the acquired companies in the post-acquisition period. In order to avoid misunderstandings we asked them also to describe the characteristics of the business strategies. In 26 acquisition cases the acquirer and acquired company have pursued an identical type of generic business strategy, whereas in 17 acquisition cases different generic business strategies have been pursued in the post-acquisition period.

In the examination of acquisition activity, the respondents were asked to evaluate their motives for the acquisition (see Table 1). One or more of these motives have been included in other merger and acquisition studies (Brouthers et al. 1998; Walter/Barney 1990; Goldberg 1983). Top managers were first asked to rate each of the motives regarding its importance for a particular acquisition deal. Scholars have suggested that the proper way to measure the strategic performance of an acquisition is to compare the acquisition's motives with its outcomes (Brouthers et al. 1998), although we tried to counter this essentially subjective approach by examining the objective criterion of value added per employee. We discovered that the managers had multiple motives for making acquisitions in Slovenia and, as a result, tried to find out whether the primary motives for these acquisitions have in fact been realised in the postacquisition period. The respondents were asked to indicate how successful the acquiring firms have been in achieving each of the potential motives. Responses ranged from (1) "not realised at all" to (5) "fully realised". We propose that, once the motives of acquisition have been identified, the success or failure of a particular acquisition can be measured by examining the extent to which those motives have been satisfied (see Table 2). 
A possible weakness of our approach is that the managers might have tried to justify their actions by assigning more importance to those motives that were actually realised. Such an ex-post rationalisation was avoided by using value added per employee as an additional criterion to measure the acquisition performance. We correlated value added per employee with the realisation of the key motives for the acquisitions (see Table 3).

\section{Results of the study}

The most important motives for horizontal acquisitions were: the transfer of skills, complementary resources between the merged companies and the synergies created by sharing activities (see Table 1). They enhance the competitive advantage of the acquired firm by lowering costs or enhancing differentiation and lead to profit maximisation. The transfer of skills and sharing of activities have been carried out through the reorganisation of marketing and supply activities and management training programmes. Our findings are consistent with some other studies. Brush's finding (1996), for example, also highlights the importance of resource sharing and activity sharing in the postacquisition period. We may argue that the motives for horizontal acquisitions do not differ significantly regarding the fit between business strategies in the postacquisition period. The differences are statistically significant at too high $\mathrm{p}$ level ( $>0.05$ ). Therefore, we cannot accept the first subsidiary hypothesis.

Table 1: Motives for horizontal acquisitions in Slovenia

\begin{tabular}{|c|c|c|c|}
\hline Motive & $\begin{array}{c}\text { Identical type of } \\
\text { generic business } \\
\text { strategy }\end{array}$ & $\begin{array}{c}\text { Different type of } \\
\text { generic business } \\
\text { strategy }\end{array}$ & Sig. \\
\hline Sharing of activities & 4.69 & 4.38 & 0.231 \\
\hline Complementary resources & 4.48 & 4.21 & 0.314 \\
\hline Transfer of skills & 4.11 & 4.28 & 0.529 \\
\hline $\begin{array}{c}\text { Strategic realignment to } \\
\text { changes in the business } \\
\text { environment }\end{array}$ & 4.09 & 4.26 & 0.616 \\
\hline Fast growth & 4.06 & 4.11 & 0.891 \\
\hline $\begin{array}{c}\text { Price of the acquired company } \\
\text { increased by the restructuring } \\
\text { costs lower than a green-field } \\
\text { investment }\end{array}$ & 4.03 & 3.84 & 0.633 \\
\hline Profit maximisation & 4.01 & 3.97 & 0.446 \\
\hline Local market share & 3.64 & 3.92 & 0.542 \\
\hline Financial synergies & 3.17 & 3.34 & 0.411 \\
\hline $\begin{array}{c}\text { To explore the potential of the } \\
\text { human resources }\end{array}$ & 3.12 & 3.29 & 0.423 \\
\hline
\end{tabular}

Scale: 1 - not important at all, 5 - very important 
Horizontal acquisitions where the acquiring and acquired companies have developed an identical type of business strategy in the post-acquisition period have outperformed acquisitions where the acquiring and acquired companies have developed different types of generic business strategies (see Table 2). For example, overall cost leadership required the aggressive construction of efficient scale facilities, the vigorous pursuit of cost reductions from experience and economies of scale, tight control of costs and overheads, cost minimisation in areas like $R \& D$, sales force, advertising, service and the avoidance of marginal customer accounts. Where both companies have developed the same generic type of business strategy, this has made the transfer of skills and sharing of activities between merged companies in the post-acquisition period easier and more efficient. The co-ordination of various activities between the merged companies has obviously been very difficult or even impossible when they have tried to compete by pursuing different generic business strategies.

We can accept the second subsidiary hypothesis by comparing the realisation of the following motives for the acquisition $(p<0.05)$ : sharing of activities; complementary resources of companies; transfer of skills; fast growth; profit maximisation and the acquisition of local market share. If we compare the realisation of other motives the performance differences are not statistically significant (see Table 2). The acquisition of an acquired company's local market share failed if companies developed different business strategies in the postacquisition period. Broadly targeted strategies emphasising low prices have resulted in lost sales with customers sensitive to features or services, whereas differentiators lost sales to price-sensitive customers. Few companies have competed successfully over an extended period on the basis of operational effectiveness. The most obvious reason for that is the rapid diffusion of best practices.

The third subsidiary hypothesis can be accepted where the acquiring and acquired companies have developed an identical type of business strategy in the post-acquisition period in cases of the following motives for acquisition: transfer of skills $(\mathrm{p}=0.03)$; sharing of activities $(\mathrm{p}=0.02)$; complementary resources $(\mathrm{p}=0.04)$; profit maximisation $(\mathrm{p}=0.04)$ and the acquisition of local market share $(\mathrm{p}=0.05)$ (see Table 3). We may argue that the performance of horizontal acquisitions in Slovenia measured by valued added per employee depends on the degree of actual realisation of two motives for acquisition: the transfer of skills and sharing of activities. The correlation between the actual realisation of these two motives on one hand and the performance of an acquisition measured by value added per employee on the other was strong and statistically significant at a relatively low p level (see Table 3 ) where a fit between the business strategies of the merged companies existed. In other words, if the acquirer and acquired company have developed an identical type of generic business strategy the realisation of some of the most important motives for acquisitions such as the transfer of skills and sharing of activities would be a relatively good indicator of 
the acquisition performance as measured by more objective criteria such as value added per employee.

Table 2: Realisation of the most important motives for horizontal acquisitions regarding fit or no fit between the business strategies of acquiring and acquired companies in the post-acquisition period

\begin{tabular}{|c|c|c|c|}
\hline Motive & $\begin{array}{c}\text { Identical type of } \\
\text { generic business } \\
\text { strategy }\end{array}$ & $\begin{array}{c}\text { Different type of } \\
\text { generic business } \\
\text { strategy }\end{array}$ & Sig. \\
\hline Sharing of activities & 4.71 & 3.59 & 0.021 \\
\hline Complementary resources & 4.57 & 3.61 & 0.018 \\
\hline Transfer of skills & 4.19 & 3.57 & 0.049 \\
\hline $\begin{array}{c}\text { Strategic realignment to } \\
\text { changes in the business } \\
\text { environment }\end{array}$ & 4.24 & 3.66 & 0.281 \\
\hline Fast growth & 4.81 & 3.43 & 0.011 \\
\hline $\begin{array}{c}\text { Price of the acquired company } \\
\text { increased by the restructuring } \\
\text { costs lower than a green-field } \\
\text { investment }\end{array}$ & 4.11 & 3.65 & 0.086 \\
\hline Profit maximisation & 4.22 & 3.11 & 0.043 \\
\hline Local market share & 4.58 & 2.37 & 0.007 \\
\hline Financial synergies & 3.82 & 3.68 & 0.323 \\
\hline $\begin{array}{c}\text { To explore the potential of the } \\
\text { human resources }\end{array}$ & 4.11 & 3.54 & 0.064 \\
\hline
\end{tabular}

* Realisation scale: 1 - not realised at all, 5 - fully realised

In contrast, the third subsidiary hypothesis cannot be accepted where the acquirer and acquired company have developed different types of generic business strategies in the post-acquisition period. The exceptions are only two motives for acquisition: complementary resources and the acquisition of local market share. Even if the acquirer and acquired company developed different types of generic business strategy in the post-acquisition period, the realisation of these two motives would be a relatively good indicator of a good acquisition performance measured by value added per employee.

\section{Discussion}

Our study is focused on the relationship between business strategies of the companies involved in the acquisition in the post-acquisition period. The results suggest that the sharing of activities and transfer of skills are important in the cases of a fit between business strategies in the post-acquisition period, whereas they do not play an important role in cases where the acquirer and acquired company pursue different types of business strategies. This finding is consistent 
with our earlier study (Lahovnik 2005). Further, we might argue that in those cases where a fit between business strategies does not exist the integration of business processes between the merged companies is not suggested. On one hand, when the acquirer and acquired company pursued different generic business strategies, complementary resources and the acquisition of local market share would be a relatively good indicators of acquisition performance while, on the other, the transfer of skills and sharing of activities would not be a good indicator.

Table 3: How realisation of the key motives influences the performance of acquisitions

\begin{tabular}{|c|c|c|}
\hline Motive & $\begin{array}{c}\text { Value added per } \\
\text { employee* } \\
\text { (Identical type of } \\
\text { generic business } \\
\text { strategy) }\end{array}$ & $\begin{array}{c}\text { Value added per } \\
\text { employee* } \\
\text { (Different type of } \\
\text { generic business } \\
\text { strategy) }\end{array}$ \\
\hline Sharing of activities & $0.81(\mathrm{p}=0.02)$ & $0.25(\mathrm{p}=0.23)$ \\
\hline Complementary resources between companies & $0.65(\mathrm{p}=0.04)$ & $0.51(\mathrm{p}=0.05)$ \\
\hline $\begin{array}{c}\text { Transfer of skills from the acquiring to the } \\
\text { acquired company }\end{array}$ & $0.77(\mathrm{p}=0.03)$ & $0.41(\mathrm{p}=0.16)$ \\
\hline $\begin{array}{c}\text { Strategic realignment to changes in the business } \\
\text { environment }\end{array}$ & $0.52(\mathrm{p}=0.17)$ & $0.49(\mathrm{p}=0.21)$ \\
\hline Fast growth & $0.12(\mathrm{p}=0.36)$ & $0.14(\mathrm{p}=0.31)$ \\
\hline $\begin{array}{c}\text { Price of the acquired company increased by the } \\
\text { restructuring costs lower than a green-field } \\
\text { investment }\end{array}$ & $0.29(\mathrm{p}=0.26)$ & $0.24(\mathrm{p}=0.33)$ \\
\hline Profit maximisation & $0.68(\mathrm{p}=0.04)$ & $0.63(\mathrm{p}=0.08)$ \\
\hline Local market share & $0.56(\mathrm{p}=0.05)$ & $0.55(\mathrm{p}=0.05)$ \\
\hline Financial synergies & $-0.11(\mathrm{p}=0.46)$ & $-0.19(\mathrm{p}=0.48)$ \\
\hline $\begin{array}{c}\text { To exploit the human resources of the acquiring } \\
\text { company }\end{array}$ & $0.12(\mathrm{p}=0.38)$ & $0.11(\mathrm{p}=0.32)$ \\
\hline
\end{tabular}

*Value added was defined as the sum of depreciation, wages and net profit

By analysing realisation of the ten most important motives for horizontal acquisitions regarding a fit or no fit between acquiring and acquired companies' business strategies in the post-acquisition period, we found that realisation of these motives is on average higher when the acquiring and acquired company develop an identical type of business strategy than when they develop different types. The results of the study revealed that compromises and inconsistencies in pursuing horizontal acquisitions eroded the competitive advantage a company had with its original varieties or target customers. For example, one trading company has been developing an overall cost leadership strategy based on the strong pursuit of cost reductions from economies of scale, tight cost control, cost 
minimisation in areas like, advertising, service, sales force and avoidance of marginal customer accounts. The company wanted to increase its market share by acquiring another company in the market that had been developing a differentiation strategy. Management of the acquirer tried to increase the operational efficiency by sharing of activities and transferring skills in the postacquisition period. Yet every company had a specific set of functional strategies to fit the target customers' needs. These differences inhibited the cross-unit interchange of skills and business practices. The broadly targeted acquisition strategy resulted in the typical stuck-in-the-middle position of merged companies in the market. Customers sensitive to features and services have been looking for other suppliers and new customers who put low price in first place have not entirely replaced those who were lost. This acquisition was later divested due to the unsatisfactory performance. The co-ordination of various activities between the merged companies is very difficult or even impossible if they try to compete by pursuing different generic business strategies within the same industry.

The management of companies involved in a horizontal acquisition should pay more attention to the strategic fit between generic business strategies. The coordination of various activities between the merged companies is very difficult, even impossible, if they try to compete by pursuing different generic business strategies within the same industry. Therefore, in such a case we would suggest that the managers maintain the autonomy of the acquired company.

\section{Conclusion}

Mergers and acquisitions are an important form of the strategic restructuring process in a post-transition economy. In spite of this fact, empirical results suggest that many acquisitions fail to achieve their strategic goals. We focused our research on the fit between the business strategies of merged companies in the post-acquisition period. The results of our study suggest that managers should consider the strategic fit between business strategies when acquiring another company within the same industry. The most important motives for horizontal acquisitions were the sharing of activities and transfer of skills. The realisation of these two motives for acquisition proved to be a relatively good indicator of acquisition performance, even when measured by more objective criteria such as value added per employee. However, the realisation of sharing of activities and transfer of skills was on average higher $(p<0.05)$ where companies have developed an identical generic business strategy. The transfer of skills and sharing of activities have been carried out through the reorganisation of marketing and supply activities and management training programmes. The realisation of some important synergies would be more difficult or even impossible if the merged companies competed in the same industry by combining completely different sets of business activities. A broadly targeted 
acquisition strategy has resulted in the typical stuck-in-the-middle position of merged companies in the Slovenian market.

\section{References}

Berkovich, E./Narayanan, M. P. (1993): Motives for takeovers: An empirical investigation, in: Journal of Financial and Quantitative Analysis, 28, 3, 347-362.

Bradley, M./Desai, A./Kim, H. E. (1988): Synergistic gains from corporate acquisitions and their divisions between the stockholders of target and acquiring firms, in: Journal of Financial Economics, 21, 1, 3-40.

Brouthers, K. D./P. V van Hastenburg/J. van den Ven (1998): If most mergers fail why are they so popular?, in: Long Range Planning, 31, 3, 347-353.

Brush, H. T. (1996): Predicted change in operational synergy and post-acquisition performance of acquired businesses, in: Strategic Management Journal, 17, 1, 1-24.

Cartwright, S./Cooper, C. (1993): The role of culture in successful organizational marriage, in: Academy of Management Executive, 7, 2, 57-70.

Čater, T./Pučko, D. (2010): Factors of effective strategy implementation: Empirical evidence from Slovenian business practice, in: Journal for East European Management Studies, $15,3,207-236$.

De Noble, A. F./Gustafson T. L./Hegert, M. (1988): Planning for post-merger integration Eight lessons for merger success, in: Long Range Planning, 21, 4, 82-85.

Dervarič, E./Medved, M./Malenković, V. (2008): Strategic factors and a model of enterprise restructuring in the coal industry in Europe with emphasis on experience in Slovenia Velenje coal mine case, in: The Southern African Institute of Mining and Metallurgy, 6, 2: 1-14.

Gates, S./Very, P. (2003): Measuring performance during M\&A integration, in: Long Range Planning, 36, 2, 167-185.

Goldberg, H. W. (1983): Mergers: Motives, Modes, Methods. Hampshire: Gower Publishing Company.

Gruca, S. T./Deepika, N./Mehra, A. (1997): Exploiting synergy for competitive advantage, in: Long Range Planning, 30, 4, 605-611.

Jarrell, G. A./Brickley, A. J./Netter, M. J. (1988): The market for corporate control, The empirical evidence since 1980, in: Journal of Economic Perspectives, 2, 1, 49-68.

Lahovnik, M. (2010): Corporate governance in Slovenia after sixteen years of transition, in: Transformations in business and economics, 9, 2, 118-127.

Lahovnik, M. (2005): Strategic factors underlying acquisitions performance in a postcommunist economy : experience from Slovenia, in: Post Communist Economies, 17, $4,503-521$.

Lubatkin, M. (1983): Mergers and the performance of the acquiring firm, in: Academy of Management Review, 8, 2, 218-225.

Morck, R./Schleifer, A./Vishny, R.W. (1990): Do managerial objectives drive bad acquisitions?, in: Journal of Finance, 45, 1, 31-48. 
Norburn, D./Schoenberg, R. (1994): European cross-border acquisitions: How was it for you?, in: Long Range Planning, 27, 4, 25-34.

Papadakis, V. M./Thanos, I. C. (2010): Measuring the performance of acquisitions: An empirical investigation using multiple criteria, in: British Journal of Management, 21, 4, 859-873.

Peljhan, D./Tekavčič, M./Marc, M./Šobota, A. (2010): Obvladovanje uspešnosti poslovanja: ali slovenska podjetja napredujejo?, in: Teorija in praksa, 47, 4, 671-691.

Penger, S./Tekavčič, M. (2008): Slovenian case of strategic change management in the public sector: towards the Lisbon Strategy, in: Zbornik radova Ekonomskog fakulteta Rijeka, $26,2,301-324$.

Porter, M. (1996): What is strategy?, in: Harvard Business Review, 74, 6, 61-78.

Porter, M. (1987): From competitive advantage to corporate strategy, in: Harvard Business Review, 65, 3, 43-59.

Very, P./Lubatkin, M./Calori, R./Veiga, J. (1997): Relative standing and the performance of recently acquired European firms, in: Strategic Management Journal, 18, 8, 593-614.

Walter, G. A./Barney, B. J. (1990): Management objectives in mergers and acquisitions, in: Strategic Management Journal, 11, 1, 79-86.

Žnidaršič, J. (2010): Age management in Slovenian enterprises: the viewpoint of older employees, in: Zbornik radova Ekonomskog fakulteta Rijeka, 28, 2, 271-301. 